\title{
PERTAMBAHAN ALAMIAH DAN DISTRIBUSI ANGKA KELAHIRAN SAPI BALI DI KOTA BAUBAU
}

\author{
Farida Asana ${ }^{1}$, La Ode Ba'a, ${ }^{2}$ Rahim Aka. ${ }^{2}$ \\ ${ }^{1}$ Alumni Fakultas Peternakan Universitas Halu Oleo \\ ${ }^{2}$ Dosen Fakultas Peternakan Universitas Halu Oleo \\ E-mail: Faridaasana@ rocketmail.com
}

\begin{abstract}
ABSTRAK
Penelitian ini bertujuan untuk mengetahui pertambahan alamiah distribusi angka kelahiran sapi bali di Kota Baubau. Diharapkan hasil penelitian ini bermanfaat sebagai informasi mengenai pertambahan alamiah dan distribusi angka kelahiran sapi bali di Kota Baubau. Penentuan lokasi penelitian di kota Baubau ditentukan secara purposive samplingyaitudi pilih 3 (tiga) kecamatan yang memiliki populasi sapi bali terbanyak yaitu (Kecamatan Bungi, Kecamatan Sorawolio dan Kecamatan Lea-lea). Pemilihan responden penelitian di tingkat desa di lakukan secara purposive sampling dengan kriteria peternak yang di jadikan responden adalah peternak yang memiliki sapi bali induk yang pernah melahirkan. Variabel yang diamati adalah jumlah populasi ternak sapi bali, persentase kelahiran, persentase kematian, dan angka kelahiran bulanan. Hasil penelitian menunjukkan bahwa nilai persentase kelahiran sapi bali sebesar 45,40\%tahun, persentase kematian sapi bali sebesar $7,86 \%$ tahun, pertambahan alamiah populasi $37,54 \%$ tahun dan rata-rata distribusi kelahiran bulanan $14 \%$ ekor/bulan dengan persentase induk yang melahirkan dalam setahun $86,08 \%$ dari jumlah total populasi induk 194 ekor. Dapat disimpulkan bahwa nilai pertambahan alamiah populasi dan distribusi angka kelahiran bulanan di Kota Baubau cukup tinggi.
\end{abstract}

Kata kunci : Pertambahan alamiah, Angka kelahiran bulanan, Sapi bali.

\begin{abstract}
The research almed to determine the natural increase and the calving rate of monthly of Bali Cattle inBaubauCity. Hopefully this research might be useful as the information regarding the natural increase and calving rate of monthly of Bali cattle in BaubauCity. Location research inBaubauCity was determined by purposive sampling with select 3 districts which has the largest populationof Bali cattle namely (BungiDistrict, District Sorawolio and Lea-lea District).Selection of survey respondents at the village level is done by purposive sampling with criteria breeders' antecedent respondents are farmers who have Bali cattle parents that have given birth.The variables measured were the number of population Bali cattle, the percentage of births, the percentage of deaths, and the births rate monthly. The results showed that the percentage of births Bali cattle $45.40 \%$ / year, the percentage of deaths of $7.86 \%$ / year, the increase of natural population of $37.54 \%$ / year and the average monthly distribution of births by $14 \%$ tail / month with the percentage of parent gave birth to $86.08 \%$ of the total population of the parent (194 tail). It can be concluded that the value of the natural increase of population and calving rate of monthly in Baubau City is quite high.
\end{abstract}

Keywords: Natural increase, monthly birth rate, Bali cattle. 


\section{PENDAHULUAN}

Upaya peningkatan populasi dan produksi ternak sapi potong di Indonesia di lakukan untuk mencukupi kebutuhan daging dalam negeri, dan mengurangi kebutuhan daging impor. Hal ini didasarkan bahwa populasi sapi potong di Indonesia pada tahun 2014 adalah 14.726.875 ekor dan tahun 2015 sebanyak 15.419.718 ekor dengan laju pertumbuhan populasi dari tahun 2014 ke tahun 2015 populasi adalah cenderung rendah (4,49\%/tahun) dari tahun 2014 ke tahun 2015 hanya 1,77\%/tahun, sementara konsumsi daging sapi dalam negeri tahun 2015 adalah 2,56kg/tahunsehingga di perlukan ketersediaan daging nasional 653.980 ton setara dengan 3.846.941 ekor sapi hidup(BPS Indonesia, 2016).

Kota Baubau merupakan salah satu Kota di Provinsi Sulawesi Tenggara yang memiliki prospek untuk pengembangan sapi potong karna di dukung dengan ketersediaan lahan pertanian yang cukup luas di beberapa Kecamatan (Kecamatan Bungi, Sorawolio, dan Lea-lea). Umumnya jenis sapi potong yang dipelihara adalah sapi bali. Kota Baubau merupakan salah satu daerah di Sulawesi Tenggara yang memiliki prospek sumber daya alam yang mendukung untuk pengembangan sapi bali. Populasi sapi bali di Kota Baubau pada tahun 2014 berjumlah 1.860 ekor. Populasi sapi bali di Kota Baubau pada tahun 2014 tersebar di 8 Kecamatan yaitu Kecamatan Bungi 975 ekor, Sorawolio 333 ekor, Lea-lea 199 ekor, Wolio 163 ekor, Betoambari 70 ekor,Murhum 61 ekor, Batu Poaro 35 ekor dan Kokalukuna 24 ekor (BPS Sultra, 2015).

Umumnya sistem pemeliharaan sapi bali dapat di bedakan menjadi 3 (tiga) cara yaitu sistem pemeliharaan ekstensif, semi intensif dan intensif. Sistem pemeliharaan ternak sapi yang berbeda tersebut dapat mempengaruhi produktivitas ternak di suatu wilayah sapi bali. Salah satu indikator untuk mengukur produktivitas ternak adalah menghitung pertambahan alami setiap tahunnya. Pertambahan alami adalah persentase selisih antara tingkat kelahiran dengan tingkat kematian dalam waktu satu tahun (Anonim,1982). Nilai pertambahan alamiah di suatu wilayah dipengaruhi oleh manajemen pemeliharaan, persentase angka kelahiran, angka kematian, jumlah induk

produktif serta ketersediaan pejantan.

\section{MATERI DAN METODE}

Penelitian ini telah dilaksanakan selama 1 (satu) bulan yaitu tanggal 27 Mei-26 Juni 2016 dan bertempat di Kota Baubau.Penentuan lokasi penelitian di tentukan secara purposive sampling yaitudi pilih 3 (tiga) kecamatan yang memiliki populasi sapi bali terbanyak yaitu Kecamatan Bungi, Kecamatan Sorawolio dan Kecamatan Lea-lea.

Data yang dikumpulkan pada penelitian ini meliputi data primer dan data sekunder. Data primer adalah data yang diperolehmelalui wawancara langsung dengan responden dan pengamatan langsung dilapangan dengan menggunakan kuesioner yang meliputi jumlah populasi ternak sapi bali, persentase kelahiran, persentase kematian, nilai pertambahan alamiah dan angka kelahiran. Sedangkan data sekunder adalah data yang diperoleh dari instansi-instansi terkait seperti Dinas Peternakan, Badan Pusat Statistik Sultra, Kelurahan, Kecamatan dan Penyuluh Pertanian Lapangan di daerah penelitian.

\section{HASIL DAN PEMBAHASAN}

\section{Jumlah Populasi Ternak Sapi Bali}

Jumlah populasi ternak sapi bali dapat di daerah penelitian terdiri atas sapi dewasa (jantan dan betina), sapi muda (jantan dan betina), pedet pasca sapih (jantan dan betina), dan pedet pra sapih (jantan dan betina) dapat dilihat pada Tabel 1. 
Tabel 1. Jumlah Populasi Sapi Bali di Lokasi Penelitian pada Tahun 2015

\begin{tabular}{|c|c|c|c|c|c|c|c|c|}
\hline \multirow{3}{*}{$\begin{array}{l}\text { Populasi Akhir } \\
\text { (Desember) }\end{array}$} & \multicolumn{6}{|c|}{ Lokasi Penelitian (Kecamatan) } & \multirow{2}{*}{\multicolumn{2}{|c|}{ Jumlah }} \\
\hline & \multicolumn{2}{|c|}{ Sorawolio } & \multicolumn{2}{|c|}{ Bungi } & \multicolumn{2}{|c|}{$\begin{array}{r}\text { Lea- } \\
\text { lea }\end{array}$} & & \\
\hline & Ekor & $\%$ & Ekor & $\%$ & Ekor & $\%$ & $\begin{array}{c}\text { Eko } \\
\text { r }\end{array}$ & $\%$ \\
\hline Jantan dewasa & 7 & 6,42 & 6 & 5,66 & 4 & 2,21 & 17 & 4,29 \\
\hline Betina dewasa & 55 & 50,46 & 53 & 50,00 & 86 & 47,51 & 194 & 48,99 \\
\hline Jantan muda & 3 & 2,75 & 1 & 0,94 & 3 & 1,66 & 7 & 1,77 \\
\hline Betina muda & 5 & 4,59 & 4 & 3,77 & 3 & 1,66 & 12 & 3,03 \\
\hline Jantan pedet pasca sapih & 10 & 9,17 & 7 & 6,60 & 16 & 8,84 & 33 & 8,33 \\
\hline Betina pedet pasca sapih & 6 & 5,50 & 3 & 2,83 & 20 & 11,05 & 29 & 7,32 \\
\hline Jantan pedet pra sapih & 12 & 11,01 & 8 & 7,55 & 18 & 9,94 & 38 & 9,60 \\
\hline betina pedet pra sapih & 11 & 10,09 & 24 & 22,64 & 31 & 17,13 & 66 & 16,67 \\
\hline Jumlah & 109 & 100 & 106 & 100 & 181 & 100 & 396 & 100 \\
\hline \multirow{2}{*}{$\begin{array}{l}\text { Populasi Awal } \\
\text { (Januari) }\end{array}$} & \multicolumn{8}{|c|}{ Kecamatan } \\
\hline & \multicolumn{2}{|c|}{ Sorawolio } & \multicolumn{2}{|c|}{ Bungi } & \multicolumn{2}{|c|}{ Lea-lea } & \multicolumn{2}{|r|}{ Jumlah } \\
\hline Mati (ekor) & \multicolumn{2}{|c|}{17} & \multicolumn{2}{|c|}{5} & \multicolumn{2}{|c|}{5} & \multicolumn{2}{|r|}{27} \\
\hline Keluar(ekor) & \multicolumn{2}{|c|}{33} & \multicolumn{2}{|c|}{23} & \multicolumn{2}{|c|}{52} & \multicolumn{2}{|r|}{108} \\
\hline Lahir (ekor) & \multicolumn{2}{|c|}{40} & \multicolumn{2}{|c|}{42} & \multicolumn{2}{|c|}{85} & \multicolumn{2}{|r|}{167} \\
\hline Masuk(ekor) & \multicolumn{2}{|c|}{0} & \multicolumn{2}{|c|}{13} & \multicolumn{2}{|c|}{29} & \multicolumn{2}{|r|}{42} \\
\hline PopulasiAkhir & \multicolumn{2}{|c|}{109} & \multicolumn{2}{|c|}{106} & \multicolumn{2}{|c|}{181} & \multicolumn{2}{|r|}{396} \\
\hline Populasi Awal & \multicolumn{2}{|c|}{119} & \multicolumn{2}{|c|}{79} & & 24 & & 322 \\
\hline Jumlah Populasi & & & & 2 & & 53 & & 359 \\
\hline
\end{tabular}

Keterangan:

- Jantan dewasa $=\geq 2$ tahun

-Betina dewasa $=\geq 2$ tahun

-Jantan muda $=13-24$ bulan

-Betina muda $=13-24$ bulan

-Jantan pedet pasca sapih $=7-12$ bulan

-Betina pedet pasca sapih $=7-12$ bulan

- Jantan pedet prasaspih $=0-6$ bulan

-Betina pedet prasapih $=0-6$ bulan

- Ternak keluar $=$ potong + jual + digaduhkan + menghibahkan

- Ternak masuk $=$ beli + hadiah + menggaduh .

Jumlah Populasi akhir ternak sapi bali pada saat penelitian yaitu mengalami peningkatan dari 322 ekor menjadi 396 ekor (meningkat 22,98\%) dengan jumlah populasi sapi bali terbanyak adalah betina induk $(48,99 \%)$ dan terendah jantan dewasa $(4,29 \%)$. Hal ini di sebabkan oleh tingginya populasi ternak induk dari jumlah populasi $(48,99 \%)$. Apabila semakin tinggi jumlah dalam suatu populasi maka diharapkan dapat berdampak terhadap peningkatan jumlah anak yang di lahirkan (laju reproduksi tinggi). Semakin banyak jumlah anak yang dilahirkan maka nilai pertambahan alamiah akan mengalami peningkatan dalam suatu 
wilayah tertentu. Selain itu peningkatan populasi selain di sebabkan oleh tingginya angka kelahiran juga disebabkan oleh rendahya angka kematian.

Berdasarkan data pada Tabel 1.Memperlihatkan bahwajumlah yang keluar cukup tinggi (108 ekor) dibandingkan ternak yang masuk (42 ekor). Jika jumlah ternak yang keluar semakin banyak dalam suatu wilayah di bandingkan ternak yang masuk maka akan menyebabkan terjadinya penurunan populasi, dan sebaliknya jika ternak yang keluar semakin sedikit di bandingkan ternak yang masuk maka akan menyebabkan peningkatan populasi. Olek karena itu, perlunya pengontrolan terhadap pengeluaran ternak sebab jika pengeluaran ternak tidak terkendali dalam kurun waktu tertentu dalam suatu wilayah dapat menyebabkan pengurasan populasi.

\section{Persentase Kelahiran}

Persentase kelahiran adalah persentase jumlah ternak yang lahir dalam kurun waktu satu tahun yang mulai di hitung dari bulan Januari sampai dengan Desember. Angka kelahiran merupakan tolak ukur paling efektif dalam mengetahui produktifitas dan kesuburan ternak suatu wilayah. Angka kelahiran ternak sapi pada daerah penelitian dapat dilihat pada Tabel 2.

Tabel 2.Persentase kelahiran Sapi Bali di Lokasi Penelitian pada Tahun 2015

\begin{tabular}{|c|c|c|c|c|c|c|}
\hline \multirow{2}{*}{ No } & \multirow{2}{*}{ Angka Kelahiran } & \multicolumn{3}{|c|}{ Kecamatan } & \multirow{2}{*}{ Total } & \multirow{2}{*}{$\begin{array}{c}\text { Rata- } \\
\text { rata }\end{array}$} \\
\hline & & Sorawolio & Bungi & Lea-lea & & \\
\hline 1 & $\begin{array}{l}\text { Jumlah Populasi } \\
\text { (ekor/tahun) }\end{array}$ & 114 & 92 & 153 & 359 & \\
\hline 2 & $\begin{array}{l}\text { Jumlah ternak yang } \\
\text { lahir (ekor/tahun) }\end{array}$ & 40 & 42 & 85 & 167 & \\
\hline 3 & $\begin{array}{l}\text { Persentase kelahiran } \\
(\% / \text { tahun })\end{array}$ & 35,08 & 45,40 & 55,73 & & 45,40 \\
\hline
\end{tabular}

Berdasarkan data pada Tabel

2.menunjukan bahwa angka kelahiran sapi bali di lokasi penelitian dalam satu tahun terakhir adalah 167 ekor dengan persentase 45,40\%. Persentase angka kelahiran yang di peroleh tidak berbeda jauh dengan dengan persentase kelahiran yang dikemukakan oleh Sumadi dkk., (2007) bahwa angka kelahiran sapi bali adalah $46,84 \%$ dari jumlah ternak yang lahir dari jumlah populasi. Budiarto dkk., (2013) mengatakan persentase angka kelahiran sapi bali terhadap populasi dalam kurun satu tahun sebesar $29,72 \%$.

Tingginya angka kelahiran sapi bali pada daerah penelitian disebabkan karena ketersedian pakan yang memadai pada lahan ataupun padang penggembalaan. Hal ini akibat kondisi iklim terutama curah hujan yang dapat berpengaruh pada ketersediaan pakan ternak di musim hujan.

\section{Persentase Kematian}

Persentase kematian yaitu persentase jumlah ternak yang mati dalam kurun satu tahun (1 periode).Sama halnya tingkat kelahiran, tingkat kematian pun menjadi salah satu penentu jumlah populasi dalam suatu wilayah. Tinggi rendahnya tingkat kematian ternak atau mortalitas dalam suatu daerah akan berpengaruh terhadap kestabilan struktur populasi ternak. Apabila tingkat kematian ternak sapi pada suatu wilayah tinggi maka nilai pertambahan alamiahakan rendah dan tingkat kematian ternak sapi pada suatu wilayah rendah maka nilai pertambahan alamiah akan meningkat. Adapun persentase kematian sapi pada daerah penelitian dapat dilihat pada Tabel 3. 
Tabel 3. Persentase kematian Sapi Bali di Lokasi Penelitian pada Tahun 2015

\begin{tabular}{clccccc}
\hline \multirow{2}{*}{ No } & \multicolumn{1}{c}{ Angka kematian } & \multicolumn{3}{c}{ Kecamatan } & Total & $\begin{array}{c}\text { Rata- } \\
\text { rata }\end{array}$ \\
\cline { 3 - 5 } & Sorawolio & Bungi & Lea-lea & & \\
\hline 1 & $\begin{array}{l}\text { Jumlah populasi } \\
\text { sampel (ekor/tahun) }\end{array}$ & 114 & 92 & 153 & 359 & \\
2 & $\begin{array}{l}\text { Jumlah ternak yang mati } \\
3\end{array}$ & 17 & 5 & 5 & 27 & \\
$\begin{array}{l}\text { Persentase kematian } \\
(\% / t a h u n)\end{array}$ & 14,91 & 5,40 & 3,27 & & 7,86 \\
\hline
\end{tabular}

Berdasarkan data pada tabel 3 . menunjukan bahwa angka kematian sapi bali terhadap populasi di lokasi penelitian dalam satu tahun terakhir (2015) adalah $7,86 \%$ dari jumlah populasi ternak sapi bali di Kota Baubau. Angka kematian ternak sapi bali di lokasi penelitian cukup tinggi, hal ini di sebabkan karena kurang terampilnya petani peternak dalam menangani ternak yang sakit, sistem pemeliharaannya ternak masih bersifat
tradisional.Hasil penelitian ini cukup tinggi di bandingkan hasil penelitian Sudrana dkk.,(2014) angka kematian sapi bali di Kabupaten Lombok Barat terhadap populasi sebesar $4,85 \%$. Sedangkan menurut Samberi dkk.,(2010) angka kematian sapi bali terhadap populasi dari KepulauanYapen Provinsi Papua sebesar 1,33\%.Tabel 4.

Tabel 4. Penyebab Kematian Ternak Sapi Bali di Lokasi Penelitian pada Tahun 2015

\begin{tabular}{clccc}
\hline \multirow{2}{*}{ No } & \multicolumn{1}{c}{$\begin{array}{c}\text { Penyebab kematian } \\
\text { ternak }\end{array}$} & \multicolumn{3}{c}{ Jumlah ternak yang mati } \\
& Sorawolio & Bungi & Lea-lea \\
\hline 1 & Penyakit & 12 & 5 & 3 \\
2 & Kecelakaan & 4 & - & - \\
3 & Keracunan & 1 & - & - \\
4 & Serangan binatang & - & - & 2 \\
& & 17 & 5 & 5 \\
& Jumlah & & 20 & \\
\hline
\end{tabular}

Penyebab kematian ternak sapi bali di dareah penelitian disebabkan karena sistem pemeliharaannya ternak masih bersifat tradisional dan kurang terampilnya peternak dalam menangani ternak yang sakit. Hal tersebut menyebabkan ternak mudah terserang penyakit, mengalami kecelakaan, keracunan dan di serang binatang pemangsa. Umumnya penyakit yang menyebabkan kematian ternak sapi bali di lokasi penelitian yaitu perut kembung, sakit mata, dan lumpuh.

\section{Pertambahan Alamiah}

Nilai pertambahan alami diperoleh dengan mengurangkan tingkat kelahiran dengan tingkat kematian dalam suatu wilayah tertentu dan waktu tertentu yang biasanya diukur dalam waktu satu tahun (Sumadi dkk., 2001).Pertambahan alamiah ternak sapi spada daerah penelitian dapat di lihat pada Tabel 5. 
Tabel 5. Pertambahan Alamiah Sapi Bali di Lokasi Penelitian pada Tahun 2015

\begin{tabular}{clcccc}
\hline No & \multicolumn{1}{|c}{ Pertambahan Alamiah } & Sorawolio & Bungi & Lea-lea & Rata-rata \\
\hline 1 & $\begin{array}{l}\text { Persentase kelahiran } \\
\text { terhadap populasi (\%) }\end{array}$ & 35,08 & 45,40 & 55,73 & 45,40 \\
2 & $\begin{array}{l}\text { Persentase kematian } \\
\text { terhadap populasi (\%) }\end{array}$ & 14,91 & 5,40 & 3,27 & 7,86 \\
3 & Pertambahan alamiah (\%) & 20,17 & 40,1 & 52,46 & 37,54 \\
\hline
\end{tabular}

Nilai pertambahan alamiah sapi bali pada daerah penelitian ini sebesar $37,54 \%$. Besarnya nilai pertambahan alamiah tergantung dari persentase induk produktif dalam populasi, tinggiya persentase kelahiran, dan rendahnya angka kematian. Hasil penelitian ini lebih tinggi jika dibandingkan dengan penelitian Sudrana dkk., (2014) mengatakan bahwa sapi bali di Kabupaten Lombok Barat nilai pertambahan alamisebesar 27,49\%. Nilai pertambahan alamiah yang di peroleh tidak berbeda jauh dengan nilai pertambahan alamiah yang dikemukakan oleh Budiarto dkk., (2013) bahwa nilai pertambahan alami sapi bali sebesar $27,40 \%$. Nilai pertambahan alamiah dalam satu periode sapi bali pada Kabupaten Konawe di daerah transmigrasi adalah 23,42\% kemudian pada daerah non transmigrasi adalah 19,86\% (Tawulo, 2011).

\section{Distribusi Angka Kelahiran Bulanan}

Angka kelahiran sebagai tolak ukur reproduksi ternak berhubungan dengan deteksi birahi, manajemen perkawinan, lama kebuntingan, lama waktu kosong, jumlah induk dan jarak beranak (Manika dkk., 1991). Angka kelahiran sapi bali setiap bulan pada lokasi penelitian dapat dilihat pada Tabel 6 .

Tabel 6. Angka Kelahiran Sapi Bali di Kota Baubau pada Tahun 2015.

\begin{tabular}{lcc}
\hline Bulan & $\begin{array}{c}\text { Jumlah induk } \\
\text { (ekor) }\end{array}$ & $\begin{array}{c}\text { Jumlah anak } \\
\text { (ekor) }\end{array}$ \\
\hline Januari 2015 & 194 & 13 \\
Februari 2015 & 194 & 14 \\
Maret 2015 & 194 & 15 \\
April 2015 & 194 & 10 \\
Mei 2015 & 194 & 8 \\
Juni 2015 & 194 & 8 \\
Juli 2015 & 194 & 11 \\
Agustus2015 & 194 & 12 \\
September 2015 & 194 & 14 \\
Oktober 2015 & 194 & 17 \\
November2015 & 194 & 20 \\
Desember 2015 & 194 & 25 \\
Jumlah & & 167 \\
\hline Rata-rata jumlah kelahiran & & 14 ekor/bulan \\
\hline
\end{tabular}


Berdasarkan data pada Tabel 6.distribusi angka kelahiran bulanan sapi bali di lokasi penelitian Kecamatan Sorawolio, Kecamatan Bungi dan Kecamatan Lea-lea dengan rata-rata kelahiran 14 ekor/bulan. Hal ini menunjukan induk sapi bali di lokasi penelitian memiliki tingkat fertilitas/kesuburan yang cukup tinggi dimana dari 194 ekor induk produktif terdapat 167 ekor induk yang melahirkan (86,085 dari populasi induk). Hasil penelitian ini di dukung oleh Pane (1991), bahwa angka kebuntingan sapi bali berkisar $83-86 \%$ dengan persentase induk yang beranak $69-81 \%$. Hasil penelitian ini lebih tinggi dibandingkan dengan penelitianIchsan (2010) menyatakan bahwa angka kelahiran di daerah transmigrasi sebesar 12,25 ekor/bulan dan pada daerah non transmigrasi sebesar 11 ekor per bulan, dan lebih tinggi dibandingkan dengan penelitian Ba'a (2001) menyatakan bahwa rata-rata angka kelahiran sapi bali selama periode Agustus 2000 sampai Juli 2001 khususnya pada daerah tegalan dan daerah irigasi menunjukan perbedaan. Pada daerah irigasi frekuensi kelahiran ternaknya yaitu 3,15 ekor/bulan lebih tinggi jika dibandingkan pada daerah tegalan yaitu sebesar 2,92 ekor.

Angka kelahiran tertinggi ternak sapi bali di Kota Baubau terjadi pada bulan November dan Desember dimana jumlah kelahiran sebanyak 20 dan 25 ekor dan terendah bulan Mei dan Juni masingmasing 8 ekor. Tingginya angka kelahiran ini berhubungan dengan ketersediaan pakan dimana pada saat itu curah hujan terjadi pada bulan Oktober-April sehingga menyebabkan menunjang pertumbuhan pakan ternak. Sedangkan pada bulan MeiSeptember terjadi musim kemarau sehingga ketersediaan pakan berkurang. Hal ini diakibatkan karena kondisi iklim terutama curah hujan yang dapat berpengaruh pada ketersediaan pakan.

\section{KESIMPULAN}

Berdasarkan hasil penelitian dapat disimpulkan bahwa:

1. Nilai rata-rata pertambahan alamiah di lokasi penelitian (Kecamatan Sorawolio, Kecamatan Bungi dan Kecamatan Lea-lea) pada Tahun 2015 adalah $37,54 \%$.

2. Rata-rata angka kelahiranbulanan sapi bali di lokasi penelitian adalah 14 ekor/bulan.

3.

\section{DAFTAR PUSTAKA}

Anonim. 1982. Buletin Statistik dan Ekonomi Ternak. Proyek Penyempurnaan Statistik Peternakan. Dit Bina Program. Ditjen Peternakan. Jakarta.

Ba'a,L.O.2001. Studi kelahiran bulanan sa pi bali pada daerah pertanian irigasi dantegalan di Kecamatan Pondidaha. Laporan Hasil Penelitian. Lembaga PenelitianUniversitasHaluoleo.

Kendari.

Badan Pusat Statistik. 2015. Sulawesi Tenggara dalam angka. Kendari.

Badan Pusat Statistik. 2016. Indonesia dalam angka. Jakarta

Budiarto, A, L. Hakim, Suyadi, VM. Ani Nurgiartiningsih dan G. Ciptadi. 2013. naturalincrease Sapi Bali Di wilayah instansi populasi Dasar Provinsi Bali. J. Ternak Tropikal. 14(2): 46-52. Fakultas Peternakan UB Malang.
Ichsan,
L.
M. 2010.
Angka kelahiran sapi bali pada daerah transmigrasi dan non transmigrasi di Kabupaten Muna.Skripsi.Fakultas Pertanian, Universitas Haluoleo, Kendari. 
Manika, W. T. I. K. Sutan, I. G. Putu dan T. D. Chaniago. 1991. Reproduksi, Tingkah Laku dan Produksi Ternak di Indonesia. Gramedia Pustaka. Jakarta.

Pane, I. 1991. Produktivitas dan breeding Sapi bali. Pros.Seminar Nasional Sapi Bali. 2-3 September 1991. Fakultas Peternakan, Universitas Hasanudin. Ujung Pandang.

Sumadi, N. Ngadiyono dan E. Sulastri. 2007. Estimasi output sapi potong di Kabupaten Sukoharjo Jawa Tengah. Makalah di sajikan pada Seminar Nasional Teknologi Peternakan dan Veteriner 2007. Fakultas Peternakan, Yogyakarta. Fakultas Peternakan, Universitas Gadjah Mada.

Sudrana, I. P., Lestari. R. Jan. T. Rozy. dan L. M. Kasip. 2014. Estimasi kebutuhan dan supply calon bibit dan bibit untuk sapi bali Di Kabupaten Lombok Barat. Jurnal Penelitian UNRAM. 18(1): Fakultas Peternakan, Universitas Mataram.

Samberi, K. Y., N. Ngadiyono., dan Sumadi. 2010. Estimasi dinamika populasi dan produktivitas ternak bapi Bali Di Kabupaten Kepulauan Yapen Regency, Propinsi Papua. Buletin Peternakan. 34(3): 167-177. Yogyakarta. Fakultas Peternakan, Universitas Gadjah Mada.

Tawulo, S. J. 2011. Pertambahan alami (Natural Increase)sapi bali di daerah transmigrasi dan non transmigrasi Kabupaten Konawe. Skripsi. Fakultas Pertanian, Universitas HaluOleo. Kendari. 